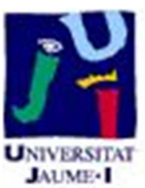

Título artículo / Títol article: Fragmentation and parts and components trade in the Western Balkan countries

Autores / Autors

Bojan Shimbov, Maite Alguacil, Celestino Suárez

Revista:

Post-Communist Economies

Versión / Versió:

Versión Pre-print

Cita bibliográfica / Cita

SHIMBOV, Bojan; ALGUACIL, Maite; SUÁREZ,

bibliogràfica (ISO 690):

Celestino. Fragmentation and parts and components trade in the Western Balkan countries. Post-

Communist Economies, 2013, vol. 25, no 3, p. 371-

391

url Repositori UJI:

http://hdl.handle.net/10234/114802 


\title{
Fragmentation and parts and components trade in the Western Balkan countries
}

\author{
Bojan Shimbov $^{\star}$, Maite Alguacil ${ }^{\dagger}$ and Celestino Suárez ${ }^{\ddagger \S}$
}

February 2013

\begin{abstract}
As a consequence of the increasing globalization and integration of the world's markets, there has been an intensive process of international fragmentation of the production over the last few decades. This phenomenon whereby previously integrated productive activities are segmented and internationally spread is reflected in the rapid increase in parts and components trade, growing at higher rates than final goods trade. In this process, the Western Balkan countries (WBC) have not been an exception. With their recent integration into the global markets, the WBC have witnessed growth in parts and components trade that has even exceeded the world average. This paper examines the determinants of the trade that stems from the international fragmentation of production in the WBC. Using a panel data set of disaggregated bilateral trade flows, we estimate gravity equations for the period 2000-2009. Our findings support the hypothesis drawn from the theory of fragmentation that trade in parts and components is motivated by labor cost differences and by geographical and proximity reasons. The relevance of additional service link costs, as well as the influence of institutional similarity and infrastructure quality or political-economic agreements is also confirmed by our empirical research.
\end{abstract}

Key words: fragmentation, trade in parts and components, Western Balkan countries, gravity model

JEL Classification: F10, F14, F15

\footnotetext{
* The World Bank and the University Jaume I of Castellón (Institute of International Economics).

† University Jaume I of Castellón (Department of Economics and Institute of International Economics). E-mail address: alguacil@uji.es.

‡ University Jaume I of Castellón (Department of Economics and Institute of International Economics). E-mail address: celes@uji.es.

$\S$ The views and conclusions in this paper express the personal standing of the authors and not necessarily the official views of their respective institutions.
} 


\section{Acknowledgements}

The authors would like to thank the helpful comments received from the participants at the $1^{\text {st }}$ Meeting on International Economics (University Jaume I of Castellón, Spain, 20/21 September 2012). They are also grateful for the financial support from the Project P21/08 of the National plan for Research and Development by the Ministry of Science and Innovation of the Spanish Government as well as the Pla de Promoció de la Investigació by Fundació Caixa Castelló-Bancaixa (P1-1A2010-05). 


\section{Introduction}

Is the label "Made in ..." on your computer telling the whole truth? The majority of manufactured products that we use on a daily basis are not made entirely in the country where they are finally assembled or sold. Most probably, some of the parts and components are provided by foreign firms. This process may go even deeper. A part or component from a particular country, used to assemble the final product, might already be composed of inputs from other countries that are used indirectly in the production of the final product. This is how international fragmentation of the production process emerges and, as a result, the creation of International Production Networks (IPN).

As shown by Jones et al. (2005), the rapid growth of parts and components trade is a natural consequence of this phenomenon, where a final good is the result of a production process that takes place in different locations. International fragmentation of production is mainly associated with the activities of Multinational Companies (MNC). This occurs when different stages of production take place in subsidiaries located in different countries, thus leading to the creation of intra-firm trade (Venables, 1999). However, this process is not confined to the activities of a MNC, but may also occur through arm's-length transactions (Venables, 1999).

The pattern of trade that emerges from international fragmentation differs depending on the reasons that drive the delocalization of the production process. As Deardorff (1998) mentioned, fragmentation of production will only occur when the benefits of this process that come from the location advantages of internationalization exceed the coordination and transportation costs of integrated production. As indicated by Jones and Kierzkowski (1990), the fragmentation process involving countries with different levels of development and income will be due to location advantages that stem from different factor endowments, such as lower wages and the availability of raw materials. Conversely, in the most advanced economies with similar incomes (mostly 
Western European countries, the US, Canada and Japan), we would expect trade in differentiated products to be driven by imperfect competition and variety preferences. According to Krugman (1980) and Krugman and Helpman (1985), in this case, trade in goods will be mainly horizontal and will not be characterized by comparative advantages, but rather by income levels, economies of scale and the number of varieties produced and consumed. Thus, in the former case firms will be mainly efficiency-seeking and oriented towards reducing production costs, while in the latter they will be serving local market demand. Consequently, researching the nature of parts and components trade will allow us to shed some light on the causes and consequences of the international fragmentation of production.

During the last decade, many studies have empirically analyzed the phenomenon of the international fragmentation of production, focusing on East Asia, the EU and the US. It is worth highlighting the work by Athukorola and Yamashita (2006) and Kimura et al. (2007) for East Asia; Baldone et al. (2001), Egger and Egger (2005) and Kaminski and Ng (2005) for EU; and Görg (2000), Swenson (2005) and Clark (2006) for the US. Studies like Yeats (2001) or Jones et al. (2005) analyze the phenomenon on a more global basis, covering countries from all three regions. A common outcome of this literature is that trade in intermediate goods is expanding more rapidly than conventional final-goods trade, as a result of the increasing disagglomeration of production. By exploiting the advantages of favorable policy settings for international production and low service-link costs, as well as inter country wage differentials, companies benefit from the international fragmentation of the production process.

In this phenomenon, the Western Balkan countries (WBC), comprising Albania, Bosnia and Herzegovina, Croatia, Macedonia, Montenegro and Serbia, are no exception. The recent economic modernization and international opening up of the WBC, as well as the spectacular increase in their trade in parts and components over the last decade makes this region an interesting case to examine. 
(Insert Figure 1 here)

As can be seen in Figure 1, annual growth in parts and components trade in the WBC is well above world growth over the last decade (except for the years 2000 and 2009). Average growth in parts and components imports and exports over the period 2000-2010 in the WBC was more than two and a half times higher than the respective world growth rate. Although there has been a decrease in the last two years due to the collapse in trade following the financial crisis, the WBC have recovered quite quickly. In 2010, WBC growth is only slightly negative, compared to the significantly negative growth rate at world level.

Using disaggregated trade data ${ }^{1}$, this paper examines the nature and determinants of bilateral trade in parts and components in the WBC. Following the empirical literature ${ }^{2}$, parts and components trade is employed as an indicator of fragmentation between the WBC and their most important trading partners. The sample period extends from 2000 to 2009 and responds to the availability of data for the whole country sample. This study considers factors that may stimulate or deter trade in parts and components as well as country-specific effects. In order to do so, a gravity panel data model is estimated. To the best of our knowledge, there has been no previous attempt to empirically test what determines international fragmentation in the WBC.

The remainder of the paper is structured as follows. In the next section we present some stylized facts. In Section 3 we analyze the theoretical background referring to the international fragmentation of the production process. Some empirical evidence is shown at the end of the section. The methodological framework and the different explanatory variables used are presented in Section 4. The following section presents and explains the empirical results and the final section concludes.

\footnotetext{
${ }^{1}$ See the Appendix for a greater detail of the used data in this work.

2 Most empirical research uses bilateral trade in parts and components as an indicator of fragmentation. See, for example, Kimura at al. (2007), Kaminski and Ng (2005) and Athukorola and Yamashita (2006).
} 


\section{Stylized facts}

Until the mid-1990s, due to political instability and war conflicts, the WBC had been beyond the direct reach of foreign firms. By the end of the decade, they had all opened up to foreign investment with the exception of Serbia and Montenegro, which opened up after the war in Kosovo in 1999 (and once former president Slobodan Miloshevic had been overthrown). One key issue in this external opening was the aspiration to join the EU. Stabilization and Association Agreements (SAA) were subsequently signed with all WBC, which initiated the long accession process that should eventually result in EU membership. ${ }^{3}$ This integration process gives the WBC the opportunity to participate more actively in the IPN.

Following the fall of the former Soviet Union and the events that followed in Eastern European countries, the WBC entered a process of economic transition to replace their former planned economic systems with market economies. Reform programs pursued aims such as liberalization, stabilization and privatization. ${ }^{4}$ In order to converge to the 'acquis communautaire', this harmonization process has expanded to areas such as market liberalization (like telecommunications and financial systems), registering property, starting up a business, protecting investors or enforcing contracts. All these measures promote a business-friendly environment and minimal disruption in transportation and communication between production segments as a necessary condition to participate in the international division of labor and trade.

\footnotetext{
${ }^{3}$ Albania submitted its application for EU membership in April 2009 and is currently a potential candidate; Bosnia and Herzegovina is also considered a potential candidate country, but formal application has not yet been submitted; Croatia is set to join the EU in July 2013, and the formal signing of the acceptance process was carried out at the EU summit in December 2011; Macedonia was granted candidate country status for EU membership in 2005, but negotiations with the EU have not yet begun due to the unresolved "name" issue with Greece; Montenegro started negotiations with the EU in June 2012; finally, Serbia was granted candidate country status at the last EU summit in March 2012.

${ }^{4}$ Barriers to trade including non-tariff barriers were removed and customs systems and legal practices were aligned with those in the EU. The trade and transport facilitation program for South Eastern Europe helped customs reforms and improved coordination between border control agencies, as well as eliminating bottlenecks at border crossings in the region.
} 
(Insert Table 1 here)

The above mentioned institutional preconditions combined with the availability of competitive overall cost structure (labor, land and utilities cheaper than new EU member countries) and geographical proximity to the $E U$, make the WBC attractive for both efficiency-seeking and market-seeking MNC. As a result of this process, foreign investment in these countries began to increase considerably. As can be seen in Table 1, Foreign Direct Investment (FDI) in each WBC displays a significant increase over the last decade, until 2008. A decline is witnessed in 2009 and 2010 due to the current financial crisis.

\section{(Insert Table 2 here)}

The implication of this process has been a significant increase in parts and components trade, as can be observed in Figure 1 in the previous section. This increase is even larger than the one experienced in final goods trade. Table 2 compares the imports and exports of final machinery and transport equipment and miscellaneous manufactured articles (hereafter machinery goods) along with imports and exports of parts and components of the same groups. ${ }^{5}$ As can be seen, world trade in parts and components (imports and exports) increased by $52 \%$ and $46 \%$ for the period 2000-2009, respectively. Western Balkan countries not only achieved faster growth in imports and exports of machinery final goods (growing at 192\% and 183\%, respectively), but also recorded even more intense growth in parts and components trade. Parts and components trade increased by $257 \%$ and $343 \%$ (in imports and exports, respectively) during the same period, which is more than double the growth rate of this type of trade at world level. Furthermore, the increase in WBC trade in parts and components is far greater than the increase in the other two regions in Europe. Compared to the EU-15, the increase is more than sevenfold, while for the EU-10, the difference is above 30

\footnotetext{
${ }^{5}$ The coverage of the parts and components included in the analysis is presented in the code list in Appendix.
} 
percentage points in the case of imports and above 90 points in the case of exports.

However, this trade is not evenly distributed across countries. Bilateral trade is mainly concentrated in only a few economic areas. The EU is the main trading partner, accounting for more than $70 \%$ of all imports and exports. Within the EU itself, the EU-15 countries (mainly Germany and Italy) are by far the most important partners. In 2000, they accounted for $67 \%$ of all machinery parts and components imports. However, that figure had dropped to $58 \%$ by 2009 due to the increase in the share of EU-10 and East Asia (mainly China). The situation on the export side has changed significantly in favor of trade with EU countries from $75 \%$ in 2000 to $83 \%$ in 2009 ).

These stylized facts reveal not only the increasing relevance of trade in intermediate goods in the WBC, but also the potential change in its geographical pattern. In order to understand the above changes, it is important to ascertain what drives the decision of firms when they choose to locate part of their production in the WBC. Discovering the nature of the IPN in these countries will help us to determine not only the pattern of trade in parts and components, but also the potential impact of this process on economic performance within this region. In order to explore this issue further, some theoretical aspects related to the international fragmentation of the production process are presented in next section.

\section{Theoretical background of the fragmentation theory}

It is a well-known fact that international trade does not only occur when each partner country is specialized in products from different industries, as explained by traditional comparative advantage theories (Ricardian model and HeckscherOhlin models). Countries may produce different types of products from the same industry, which gives rise to intra-industry trade (IIT). 
The concept of intra-industry trade was first introduced by Grubel and Lloyd (1971, 1975). The understanding of this type of trade was further formalized in theoretical terms by Krugman (1980) and Krugman and Helpman (1985), who provide seminal contributions along the lines of Dixit and Stiglitz (1977). According to these models, trade flows between industrialized countries should not be characterized by comparative advantages. Conversely, the exchange of homogeneous goods (horizontal IIT) is driven by imperfect competition and variety preferences.

However, intra-industry trade in intermediate goods is not fully explained by these initial models of horizontal IIT. The specialization pattern of trade in intermediate goods seems to be more appropriately explained by the literature on vertical IIT and the international fragmentation of the production process. ${ }^{6}$ As stated by Jones et al. (2002), international fragmentation or the splitting-up of an initially integrated production process into two or more production segments that are located in different countries, will result in vertical IIT. In this sense, while the traditional theory of trade does not fully explain why horizontal IIT takes place, it does justify vertical specialization and hence the international fragmentation of production. The first general framework to analyze fragmentation was introduced by Jones and Kierzkowski (1990). For these authors, the fragmentation of the production process into several stages located in different countries allows firms to select locations that are better suited in terms of factor endowments or productivities. This would imply, on the one hand, that the most labor-intensive stages of the production process are located in the most labor-abundant (lower wage) countries. On the other hand, as the different stages of the production process might require different labor skills, some countries' labor skills might be more appropriate to one stage than others (Ricardian productivity differences). ${ }^{7}$

However, the delocalization of the production process needs to be coordinated and linked, which will entail service link costs such as transportation,

\footnotetext{
${ }^{6}$ Vertical IIT is defined as the simultaneous exporting and importing of products in the same industry, but at a different stage of production.

${ }^{7}$ See, for example, Arndt (1997), Deardorff (2001a), or Arndt and Kierzkowski (2001).
} 
communication and other coordination activities. Due to the fact that the increasing output of the different production stages would only slightly increase total service link costs, the larger the size of the firm and the market, the more cost-efficient the fragmentation would be. Therefore, with service-link costs the scale matters. In this sense, the ideas of the new trade theory and new economic geography, concerning increasing returns to scale are also contemplated by the fragmentation literature. Indeed, fragmentation will occur if each production stage is more closely matched to its factor intensities and factor productivities in order to offset the increase in service link costs. As Jones and Kierzkowski (1990) conclude, fragmentation can lower total production costs only at the expense of higher service link requirements. ${ }^{8}$

The international fragmentation of production therefore allows a more in-depth specialization to take place within a single industry. On the one hand, a country that does not have a comparative advantage in each stage of the production process will be able to specialize in the assembly of a final good. On the other hand, a country that does not have a comparative advantage in the production of a final good will be able to produce at least some parts of that good. Both processes will eventually increase trade in intermediate goods (Deardorff 1998 and 2001a).

\section{Related research}

Many empirical works have analyzed the determinants of the international fragmentation of production. These studies differ in terms of the countries analyzed, the methodologies and data employed and/or the results. Different authors even employ dissimilar terms and measures to basically describe the same phenomenon. ${ }^{9}$ The strictest definition of this process entails the wellknown outward processing trade. That is, in this case the home-country firm

\footnotetext{
${ }^{8}$ Other important contributions to the theory of fragmentation can be found in Arndt (1997), Arndt and Kierzkowski (2001), Jones and Kierzkowski (2001b) and Deardorff (2001a).

${ }^{9}$ Such as slicing up the value chain (Krugman 1995), outsourcing (Feenstra and Hanson 1997), disintegration of production (Feenstra 1998), intra-product specialization (Arndt 1997), vertical specialization (Hummels et al. 2001), or fragmentation (Jones and Kierzkowski 1990; Deardorff 2001a).
} 
exports intermediate goods for further processing in a foreign country, after which the goods are re-imported by the home-country firm. A broader definition of fragmentation measures this process through volumes of trade flows in intermediate goods or components (Baldone et al. 2001, Yeats, 2001, Athukorola and Yamashita ,2006 and Kimura et al., 2007).

The focus of most of these studies has been on the three main economic regions in the world: the US, the EU and East Asia. International fragmentation of the production process by US firms is, for instance, studied by Swenson (2005) and Clark (2006). The first study analyzes the cross-country pattern of US outsourcing activities between 1980 and 2000. It explains how outsourcing is affected by cost changes in different host countries. The study finds that US outsourcing activities will increase as these costs fall or when a competitor country's costs rise. Clark (2006) investigates the determinants that influence US firms to engage in vertical specialization. This research shows that the main reason for US firms to engage in fragmentation is to counter a comparative disadvantage in home production. For this author, the factors that influence the selection of new locations include market size, proximity to foreign countries, political freedom, degree of exchange rate distortion and labor force availability and quality.

Studies that analyze the fragmentation process in Europe include the papers by Egger and Egger (2005) and Kaminski and Ng (2005). Egger and Egger (2005) use data on the bilateral outward and inward processing exports and imports of the EU-12 economies. The authors find that the EU's outward processing trade is to a relatively large extent determined in line with standard Heckscher-Ohlin arguments. Furthermore, they argue that for outward processing trade, infrastructure variables (such as the telephone and road networks or the electricity supply in the partner country) are also relevant. Kaminski and $\mathrm{Ng}$ (2005) analyze the case of the new EU member countries (EU-10) by investigating whether these countries have become part of the production and 
distribution networks, concluding that they had been integrated into the global networks.

Athukorala and Yamashita (2006) and Kimura et al. (2007) study the international fragmentation of production in East Asia through the estimation of gravity equations. They find not only that parts and components trade is expanding more rapidly than final goods trade in East Asia, but also that the degree of dependence on this form of international specialization is proportionately larger in East Asia than in North America or Western Europe. This seems to be the result of the relatively more favorable policy setting for international production in the region (agglomeration benefits and wage differentials), which is in line with the basic fragmentation literature. Comparing East Asia to Western Europe, Kimura et al. (2007) conclude that the fragmentation theory is well suited to explaining the mechanics of international production and distribution networks in East Asia, while the traditional horizontal product differentiation model better explains intraindustry trade between Western European countries. They also show that the difference in service-link costs and location advantages are empirically relevant and play a significant role in determining the magnitude of trade in machinery parts and components, as stated by the fragmentation literature. ${ }^{10}$

Jones et al. (2005), who analyze the areas of NAFTA, EU-15 and East Asia, conclude that the optimal degree of fragmentation depends on the size of the market, as the scale of production would determine the length to which such a division of labor can proceed. The importance of the size of the market on trade and fragmentation can be also found in the research by Egger and Falkinger (2002 and 2003b) and Burda and Dluhosch (2002).

The conclusion drawn from the brief review of the literature on fragmentation is that not only factor endowment differences, but also service-link costs are the main driving forces behind the fragmentation of the production process and consequently of trade in parts and components. These service-link costs include

\footnotetext{
${ }^{10}$ Other studies that highlight the importance of service-link and location advantages include Bergstrand and Egger (2006) and Golub et al. (2007).
} 
aspects such as political settings, institutional and infrastructure quality. Hence, here we consider these factors as the key determinants of parts and components trade.

\section{Empirical analysis}

\section{MODEL SPECIFICATION AND ESTIMATION METHODOLOGY}

Following previous empirical research, we analyze the nature of trade in parts and components in the Western Balkans by estimating a gravity model. ${ }^{11}$ This model, initially developed by Tinbergen (1962) and later expanded by Anderson (1979), explains the volume of bilateral trade flows according to the size of the trading economies and bilateral trade costs (variables such as physical distance, common border or language are considered).

Despite lacking strong theoretical foundation, gravity models have shown significant empirical robustness and explanatory power for describing trade flows. Recently, Bergstrand and Egger (2010) developed a theoretical model that encompasses bilateral final goods trade, intermediate goods trade and foreign direct investment flows. This model simultaneously estimates gravity equations for all these flows.

The gravity equation employed in this research augments the standard gravitytype variables i.e. economic size (size), distance (dist), and common border (border) with other factors that have been suggested by the fragmentation literature, such as differences in factor endowments (endow) and market size dissimilarities (ssize). We also include variables that take into account the quality of infrastructure, institutional similarity or political-economic agreements $\left(X_{k}\right)$.

More specifically, the estimating equation takes the following form:

\footnotetext{
${ }^{11}$ Gravity models have been widely used in the empirical literature of trade in parts and components. See, for instance, the papers by Athukorala and Yamashita (2006) and Kimura et al. (2007).
} 


$$
\begin{aligned}
\ln \left(\text { pctrade }_{i j t}=\right. & \beta_{0}+\beta_{1} \text { size }_{i j t}+\beta_{2} \text { dist }_{i j}+\beta_{3} \text { border }_{i j}+\beta_{4} \text { endow }_{i j t}+\beta_{5} \text { ssize }_{i t}+ \\
& +\sum_{k} \gamma_{k} X_{k, i j t}+\lambda_{t}+\mu_{i j}+\varepsilon_{i j t}
\end{aligned}
$$

where $i$ and $j$ are home and host-country indexes, respectively and $t$ denotes time. The error term comprises (fixed or random) unobserved bilateral effects, $\mu_{i j}$, and the remaining error $\varepsilon_{i j t}$, assumed to be independent across countries and over time. The countries included in the data set are presented in Appendix (Table A1). The years analyzed are 2000, 2003, 2006 and 2009. ${ }^{12}$ As mentioned, the dependent variable stands for the trade flows in parts and components between the WB country and its trading partner. The definitions and sources of all variables are detailed in Table A2 from the Appendix .

The above equation has been estimated using a panel data approach. This methodology allows us to control for country-specific differences in technology, production and socioeconomic factors, thus avoiding the misspecification problems that individual heterogeneity involves. ${ }^{13}$ Moreover, it is a well known fact that panel data provide more degrees of freedom, less collinearity and therefore more efficiency. The decision regarding whether to consider unobserved country-specific effects as fixed or random was made on the basis of the Hausman test. The models have been estimated with both home-country and country-pair effects. ${ }^{14}$ For the sake of robustness, we have also estimated the model using Ordinary Least Squares (OLS). The results of these last estimations are available upon request.

\section{DATA AND VARIABLES}

Data for parts and components trade (pctrade) were drawn from the United Nations Commodity Trade Statistics Database (UN Comtrade database) using the Standard International Trade Classification (SITC) Revision 3. Machinery and transport equipment (group 7) and miscellaneous manufactured articles (group 8)

\footnotetext{
${ }^{12}$ Data for 2004 were used for Serbia and Montenegro because data for 2003 were not available.

13 See Hsiao (1986).

${ }^{14}$ The Hausman test has been obtained from the models with country-pair effects.
} 
provide the basis for the empirical analysis. It contains a total of 145 product categories.

Trade in parts and components includes imports of country $i$ from country $j$, as well as exports from country $i$ to country $j$, for which data on parts and components are available. Hence, not only parts and components imports are considered, but also two-way trade volumes between countries. There are 5 different groups (the WBC) in total out of which each country is analyzed according to its bilateral trade relations with a set of 20 country pairs.

Following previous applications of the gravity model, we use home and foreign country GDP to measure market size, (Egger and Egger, 2005). The importance of this variable for the international fragmentation of production has been emphasized on many occasions. According to Jones et al (2005), the optimal degree of fragmentation depends on the size of the market, as long as the scale of production determines the length to which such a division of labor can proceed. This idea would be in line with the new theory of trade under imperfect competition. For Grossman and Helpman (2005), in a 'thicker market' that includes a greater number of firms, it should be easier to find a partner firm with the appropriate skills and technology to produce the fragmented component. So, the larger the international market, the greater the opportunities to produce differentiated intermediate goods.

The new trade theory and new economic geography models have further pointed out the importance of differences in market size in determining the pattern of trade (Helpman, 1987). According to these models, the more similar countries are in size, the larger the share of IIT. Thus, trade in parts and components should be positively affected by the fact that trading partners are more similar in 
size. The similarity of market size is captured here by the similarity index proposed by Helpman (1987). ${ }^{15}$

As noted previously, the exploitation of comparative advantages that stems from differences in relative factor endowments is viewed by many authors as one of the main reasons for international fragmentation (Arndt 1997; Deardorff 2001a; Jones and Kierzkowski 1990 and 2001b). According to these authors, international fragmentation is more likely to occur between countries with different factor endowments, based on the standard comparative advantage justification for trade. As in other applications of the gravity model, we proxy the differences in factor endowments by the difference in per capita GDP between the WBC and their trading partners.

Transportation costs (measured by geographical distance) between production stages are commonly used as service-link costs (Kimura et al., 2007). Bergstrand and Egger (2006) suggest that the level of trade costs should negatively impact the share of intra-industry trade. According to Athukorala and Yamashita (2006) and Golub et al. (2007), transportation costs might be more relevant for trade in parts and components than for trade in final goods. They argue that transportation costs would rise due to the number of shipments among different production stages before final assembly takes place. We also include a common border dummy and two regional variables (saa and yugo) that take into account whether or not the WB country has signed a Stabilization and Association Agreement (SAA) with the EU and whether or not the trading partners are republics of the former Yugoslavia, respectively.

More recently, many studies have also insisted on the importance of the quality of infrastructure and institutional differences in the international fragmentation of

\footnotetext{
${ }^{15}$ The similarity of country size index à la Helpman (1987) is defined as: $\log \left[1-\left(\frac{G D P i t}{G D P i t+G D P j t}\right)^{2}-\left(\frac{G D P j t}{G D P i t+G D P j t}\right)^{2}\right]$, where indices $i$ and $j$ refer to home and foreign countries, respectively, $t$ denotes time and GDP is a country's real GDP.
} 
production. ${ }^{16}$ Infrastructure (infra) is viewed as a cost-effective means of lowering trade costs and thereby promoting the internationalization of firms. For Francois and Manchin (2007), propensity to take part in a trading system depends on access to well-developed infrastructure. Insofar as higher quality infrastructure reduces communication and coordination costs, a positive impact of this variable on trade in parts and components is expected. As shown by Cheptea (2007), an improvement at the institutional level promotes trade integration. According to this author, homogeneity in the quality of institutions (instit) may also enhance trade in parts and components. Similar norms of behavior and levels of trust in doing business may make trading between countries easier (Beugelsdijk and van Schaik, 2001). Institutional similarity means that firms will be more familiar with the formal procedures and informal practices in the other country.

In our model, we have also included the relative exchange rate of the country (exch). Previous empirical work (Swenson, 2000) shows a significant and negative impact of dollar depreciation on outward processing in the case of US firms in terms of foreign inputs becoming more expensive. In this line, currency depreciation in the WBC might have a positive impact on parts and components exports to their trading partners. Finally, we have added foreign direct investment in the home country $(f d i)$ as an explanatory variable. As the affiliates of the MNC are a direct result of capital flows in the form of FDI in the host country, we would expect this variable to have a positive impact on trade in parts and components. Affiliates usually perform final assembly or processing stages using imported intermediate goods from the parent firm. According to Feenstra and Hanson (1997), the growth of capital stock in the host country encourages the flow of intermediate goods for further processing between the two countries.

\section{ESTIMATION RESULTS}

Table 3 presents the estimate coefficients for parts and components trade with home-country specific effects. For comparative purposes, we also present these

\footnotetext{
${ }^{16}$ See, for instance, the work by Egger and Egger (2005) and Jones et al. (2005).
} 
estimations for final goods trade in Table $4 .^{17}$ These models have also been estimated with country-pair effects and results are shown in Tables A3 and A4 in Appendix, respectively.

In these tables, two different models are estimated for each trade flow: a baseline model that includes the standard gravity variables together with the factor endowment variable and similarity in size (Model 1) and an extended model, which adds other country-specific variables (Model 2). Both imports and exports, as well as total trade (imports plus exports), have been calculated.

\section{(Insert Tables 3 and 4 here)}

As can be seen, the outcomes generally support the hypothesis drawn from the fragmentation literature regarding the importance and signs of the explanatory variables. While greater distance discourages bilateral parts and components trade in the WBC, market size significantly promotes it. This last circumstance is in line with the hypothesis that fragmentation of production becomes more costefficient the larger the market (Jones and Kierzkowski 1990). Similar findings are presented in Jones et al. (2005) and Kimura et al. (2007). Furthermore, the results are generally the same for all regressions in both models with homecountry and country-pair effects, suggesting that the results are robust across specifications.

As expected, the distance variable is negative and strongly significant, verifying the hypothesis that distance-related service-link costs may deter trade in parts and components. According to Jones and Kierzkowski (2001), international fragmentation is more favorable when service-link costs are lowered. Furthermore, if we look at exports and total trade this coefficient is clearly higher for parts and components than for final goods trade. This would imply that the influence of distance-related costs on the IPN is greater due to the nature of the production process and multiple border crossings.

\footnotetext{
${ }^{17}$ The outcomes of estimating total trade in SITC Rev. 3 groups 7 and 8 are available upon request.
} 
The variable that represents similarity in country size also displays the expected positive and significant coefficient in parts and components imports and total trade. However, we find a negative relationship between country-size similarity and exports of parts and components. One possible explanation for this surprising result could be that WBC trade shifted towards the EU countries during the considered period (as presented in Section 2). These countries are quite different in relative country size to the WBC.

In line with the predictions made by models on vertical IIT, significant differences in GDP per capita have a positive influence on both imports and exports. As mentioned previously, in these models the volume of vertical trade or fragmentation tends to increase the greater the differences in factor endowments and factor prices between two countries. Hence, our estimations would support the hypothesis that efficiency seeking is an important determinant in the parts and components trade of the WBC. This variable is significant for exports in parts and components, explaining the marked increase in exports from the WBC presented in Section 2. Similar findings are observed in Egger and Egger (2005).

Our results also show that the greater the degree of similarity in institutions (economic freedom and legal certainty) in trading partner countries, the more trade flows in parts and components. This is consistent with the idea that institution quality is relevant for both establishing affiliates for processing parts and components in partner countries and for companies becoming trading partners when dealing with arm's-length transactions. Moreover, the coefficients for this variable are more relevant for parts and components than for final goods trade. This reflects that regulatory issues and institutional similarity are more important when firms need to engage in production partnerships, compared to single trade relations in final goods.

As mentioned above, another determinant related to service-link costs is the quality of infrastructure. This variable records a clearly positive and significant influence on bilateral trade in parts and components. This coincides with the 
results obtained by Jones et al. (2005) and Egger and Egger (2005). Both studies conclude that infrastructure quality as part of service-link costs is extremely relevant in promoting parts and components trade. Furthermore, in view of the fact that there are more shipments between production segments within the IPN, infrastructure quality markedly favors parts and components trade when compared to final goods trade.

Although the shared border dummy has the expected positive sign, it becomes insignificant in the extended model once we control for other variables, such as infrastructure, institutions and regional trade. This is not surprising if we consider that the WBC do not share a border with their most important trading partners (the EU-15), as presented in Section 2. We also find the yugo dummy variable highly significant in all regressions. The coefficient of this variable is considerably higher in trade in parts and components than in the other two types of trade, suggesting the presence of intra-regional ties and the potential of intra-regional production networks, reflected by the trade in parts and components. However, the dummy variable for SAA is not significant in either imports or exports. This could be due to the fact that the only two countries that had signed SAA before 2007/2008 were Croatia and Macedonia, so the overall impact on the region is small.

The coefficient for the bilateral exchange rate, albeit insignificant, appears to have a positive impact on exports of parts and components and total trade, which confirm the idea that a devaluation of the currency will foster exports of parts and components. One possible explanation for this variable not being significant would be that most of the sample countries have a de facto peg to the euro.

Interestingly, the results for the FDI variable are rather mixed. We should interpret this outcome with a certain degree of caution since there were no disaggregated data for FDI by country of origin for the WBC to match the FDI flows with the respective bilateral trade in parts and components. Moreover, 
excluding this variable from the model does not affect the significance of the other variables (results are available upon request).

From the above empirical outcomes, we can derive the following conclusions. First, our findings support the idea that the fragmentation process in the WBC is not only efficiency-seeking but also market-seeking. Firms that seek to lower their production costs through fragmentation should look to larger markets in the region, as market size determines the cost-efficiency of the service-link costs this process entails. But the importance of market size may also indicate that marketseeking decisions for locating some firms are also playing an important role. Second, geographical and institutional distance will discourage trade in parts and components. According to our results, policies designed to implement incentives for foreign investors are not sufficient to participate in the IPN. Improving the institutions to alleviate cost should be considered a priority strategy for policymakers. Third, governments should also recognize that developing quality infrastructure in the region is of vital importance to join the international division of labor and trade, as a higher quality of infrastructures promotes trade integration. Finally, they should be more aware of the high trade potential to be exploited from the intra-regional ties between the republics of the former Yugoslavia, especially in developing regional production networks.

\section{Conclusions}

A specific form of international production emerges when some stages of the production process are located in several countries attending to different country characteristics. International fragmentation and international production networks are thus created. The result of this process is increased cross-border trade in parts and components.

Throughout the last decade, the WBC have witnessed a substantial increase in trade in parts and components. This suggests that the WBC, as part of their economic modernization process, have played an active role in production- 
sharing networks, especially within the Europe. Thus, identifying the nature and determinants of this type of trade is of particular interest.

According to the fragmentation literature, factor endowment differences and service-link costs are the driving forces behind the fragmentation of the production process. This theory is confirmed by our estimates, which show how factor endowment differences and market size significantly increase the fragmentation of production in this region, while distance deters it. As expected, these variables have a greater impact on trade in parts and components than on final goods trade.

Infrastructure quality also seems to be of great importance when establishing international production networks. Significant payoffs could be obtained from improving the infrastructure in the WBC, as reliable and inexpensive infrastructure facilitates the fragmentation process.

The degree of similarity in economic freedom and legal certainty in trading partner countries represents another key factor for parts and components trade in the region. Once again, the influence is much greater on parts and components trade than on final goods trade. This result supports the fact that institutional framework is more relevant when locating part of the production process abroad or performing arm's-length transactions.

Finally, our estimates confirm that, as predicted by the theory on international fragmentation, a reduction in the cost of trade associated with regional integration processes has favoured the international division of production processes. We find that the regional ties between the republics of the former Yugoslavia are still very active, even after a decade of wars and conflicts. The importance of these effects is seemingly higher for parts and components trade than for final goods trade.

The results of this study are in line with the established fragmentation literature and provide support for the main arguments therein. We are aware that the 
determinants of the international fragmentation of production might differ from industry to industry depending on countries' patterns of specialization. Thus, a future avenue of research to draw more detailed policy implications could be to perform an in-depth industry-by-industry analysis. 


\section{References}

Anderson, J. E. (1979). 'A Theoretical Foundation for the Gravity Equation', American Economic Review, 69(1), pp.106-116.

Arndt, S. W. (1997). 'Globalization and the Open Economy', North American Journal of Economics and Finance, 8(1), pp. 71-79.

Arndt, S. W. and Kierzkowski, H. (2001). 'Fragmentation: New production and trade patterns the world economy', Oxford University Press, Oxford.

Athukorola, P. and N. Yamashita (2006). 'Product Fragmentation and Trade Integration: East Asia in Global Context', North American Journal of Economics and Finance, 17, pp. 233-56.

Baldone S., Sdogati F., Tavoli L. (2001). 'Patterns and determinants of international fragmentation of production: evidence from outward processing trade between the EU and the countries of Central- Eastern Europe', Review of World Economics (Weltwirtschaftliches Archiv) 137(1), pp. 80-104

Bergstrand, J. H. and P. Egger (2006). 'Trade Costs and Intra-Industry Trade', Review of World Economics (Weltwirtschaftliches Archiv), 142(3), pp. 433-458.

Bergstrans, J. H. and P. Egger (2010), 'A General Equilibrium Theory for Estimating Gravity Equations of Bilateral FDI, Final Goods Trade, and Intermediate Goods Trade' in Steven Brakman and Peter van Bergeijk (eds.), The Gravity Model in International Trade: Advances and Applications, Cambridge, UK: Cambridge University Press

Beugelsdijk, S. and A.B.T.M. van Schaik (2001). 'Cultuur en economie', Tijdschrift voor Politieke Ekonomie, 23, pp. 69-84.

Burda, M. C. and B. Dluhosch (2002). 'Cost Competition, Fragmentation and Globalization', Review of International Economics, 10(3), pp. 424-441.

Cheptea A. (2007). Trade liberalization and institutional reforms, Economics of Transition, 15(2), pp. 211-255.

Clark, D. P. (2006). 'Country and Industry-level Determinants of Vertical Specializationbased Trade', International Economic Journal, 20, pp. 211-15.

Deardorff, A.V. (1998). 'Fragmentation Across Cones', Working Papers 427, Research Seminar in International Economics, University of Michigan, Ann Abor.

Deardorff, A. V. (2001a). 'Fragmentation in Simple Trade Models', North American Journal of Economics and Finance, 12,(2), pp. 121-37.

Dixit, A. K and Stiglitz, J. E. (1977). 'Monopolistic Competition and Optimum Product Diversity', American Economic Review, 67 (3), pp. 297-308. 
Egger, H. and J. Falkinger (2002). 'Industry Concentration, International Outsourcing and Economic Fundamentals', mimeo, presented at the 4th Annual Conference of the European Trade Study Group, September.

Egger, H. and J.Falkinger (2003b). 'The Role of Public Infrastructure for Firm Location and International Outsourcing', mimeo, presented at the 8th Annual Conference on Dynamics, Economic Growth and International Trade, May.

Egger, H. and P. Egger (2005). 'The Determinants of EU Processing Trade',The World Economy, 28, pp. 147-68.

Feenstra, R. C. (1998). 'Integration of trade and disintegration of production in the global economy', Journal of Economic Perspectives, 12, pp. 31-50

Feenstra, R. C. and G.H. Hanson (1997). 'Foreign direct investment and relative wages: evidence from Mexico's Maquiladoras', Journal of International Economics, 42, pp. 371-393.

Francois, J and M. Manchin (2007). "Institutions, Infrastructure, and Trade," CEPR Discussion Paper No. 4152.

Golub, S. S., Jones, R. W., Kierzkowski, H. (2007). 'Globalization and country-specific service links', RCER working paper No. 532

Görg, H. (2000). 'Fragmentation and Trade: US Inward Processing Trade in the EU', Review of the World Economics (Weltwirtschaftliches Archiv), 136, pp. 403-22.

Grossman, G. M., E. Helpman (2005). 'Outsourcing in a global economy', Review of Economic Studies, 72, pp. 135-159

Grubel, H. and P. J. Lloyd (1971). 'The Empirical Measurement of Intra-industry Trade', Economic Record, 470, pp, 494-517.

Grubel, H. and P. J. Lloyd (1975). 'Intra-Industry Trade: Theory and Measurement of International Trade in Differentiated Products', John Wiley, New York.

Helpman, E., (1987). "Imperfect competition and international trade: Opening remarks," European Economic Review, 31 (1-2), pp. 77-81.

Helpman, E. and P. Krugman (1985), 'Market Structure and Foreign Trade: Increasing Returns, Imperfect Competition, and the International Economy',MIT Press, Cambridge, MA.

Hummels, D., Ishii, J., Yi K-M. (2001). 'The nature and growth of vertical specialization in world trade', Journal of International Economics, 54(1), pp. 75-96

Hsiao C. (1986). Analysis of Panel Data, Cambridge University Press, Cambridge,

Jones, R. W. and H. Kierzkowski (1990). 'The Role of Services and Production in International Trade: A Theoretical Framework', in R. W. Jones and A. O. Krueger 
(eds.), The Political Economy of International Trade: Essays in Honor of Robert E. Baldwin, Basil Blackwell, Malden, MA, pp. 31-48.

Jones, R. W. and H. Kierzkowski (2001b). 'A Framework for Fragmentation', in S. W. Arndt and $\mathrm{H}$. Kierzkowski (eds.), Fragmentation: New Production Patterns in the World Economy , Oxford University Press, Oxford, pp. 17-34.

Jones, R. W., H. Kierzkowski and G. Leonard (2002). 'Fragmentation and Intra-industry Trade', in P. J. Lloyd and H. H. Lee (eds.), Frontiers of Research in Intra-industry Trade , Palgrave Macmillan, Basingstoke, pp. 67-86.

Jones, R., H. Kierzkowski and C. Lurong (2005). 'What Does the Evidence Tell Us About Fragmentation and Outsourcing', International Review of Economics and Finance, 14, pp. 305-16.

Kaminski, B. and F. Ng (2005). 'Production disintegration and integration of Central Europe into global markets', International Review of Economics \& Finance, 14(3), pp. 377-390.

Kimura, F., Y. Takahashi and K. Hayakawa (2007). 'Fragmentation and Parts and Components Trade: Comparison between East Asia and Europe', North American Journal of Economics and Finance, 18, pp. 23-40.

Krugman, P. (1980) 'Scale economies, product differentiation, and the pattern of trade', American Economic Review, 70, pp. 950-959.

Krugman P. (1995). 'Growing world trade: causes and consequences'. Brooking Papers on Economic Activity, 1, pp. 327-377.

Swenson, D. L. (2000). 'Firm Outsourcing Decisions: Evidence from U.S. Foreign Trade Zones', Economic Inquiry, 38(2), pp. 175-89.

Swenson, D. L., (2005). "Overseas assembly and country sourcing choices," Journal of International Economics, 66(1), pp. 107-130.

Tinbergen, J. (1962). 'Shaping the World Economy: Suggestions for an International Economic Policy', The Twentieth Century Fund, New York.

Venables, A. (1999). 'Fragmentation and Multinational Production', European Economic Review 43(4-6), pp. 935-945.

Yeats, A. J. (2001). 'How big is global production sharing?' in Arndt S. W. and H. Kierzkowski (eds). Fragmentation: new production patterns in the world economy, Oxford University Press, Oxford, pp. 108-144 


\section{Appendix}

We considered the Standard International Trade Classification (SITC) Revision 3 as the most appropriate in terms of detail, time, length and comprehensiveness. The groups used in our data are machinery and transport equipment (group 7) and miscellaneous manufactured articles (group 8). The goods classified as parts and components are listed below and the rest of the goods in groups 7 and 8 are classified as final goods.

\section{Code list:}

$7119,7128,7131,7132,7133,7138,7139,71441,71449,7149,7169,71819,71878,71899,72$ $119,72129,72139,72198,72199,7239,72439,72449,72467,72468,72488,7249,7259,7268$ $9,7269,72719,72729,72819,72839,72847,7285,7351,7359,73719,73729,73739,73749,7$ $4128,74135,74139,74149,74159,74172,7419,7429,7438,7439,74419,7449,, 74519,7452$ $9,74539,74568,7459,7469,7479,74839,7489,7491,7591,7599,7649,77129,7722,7723,77$ $24,7725,7726,7728,77429,77549,77579,77589,7761,7762,7763,7764,77688,77689,778$ $17,77819,77829,77833,77835,77848,77869,77879,77883,77885,7889,7841,7842,7843$, $78535,78536,78537,78689,7919,7929,81211,81215,81219,8138,8139,82119,8218,8711$ $9,87139,87149,87199,87319,87329,87412,87414,87424,8742,87426,87439,87449,8745$ $87456,87469,87479,8749,88114,88115,88123,88124,88134,8136,8859,89111,89113,89$ $12,8919,8941,8989,89935,89937,89949$ 
Table A1. Regions and countries included in the dataset

\begin{tabular}{ll}
\hline $\begin{array}{l}\text { Region } \\
\text { Bestern }\end{array}$ & $\begin{array}{l}\text { Country } \\
\text { Serbia }\end{array}$ \\
EU-15 & $\begin{array}{l}\text { Austria, Belgium, France, Germany, Greece, Italy, Luxemburg, Netherlands, } \\
\text { Sweden, United Kingdom }\end{array}$ \\
EU-10 & Bulgaria, Czech Republic, Hungary, Slovenia \\
EFTA & Switzerland \\
East Asia & China, Japan \\
Others & Turkey \\
\hline
\end{tabular}

${ }^{18}$ The EU-10 countries are: Bulgaria, the Czech Republic, Hungary, Slovenia, Slovakia, Romania, Latvia, Lithuania, Estonia and Poland 
The table below presents the definition of each of the variables used and the data sources.

Table A2. Definitions and data sources

\begin{tabular}{|c|c|c|}
\hline Abbreviation & Definition & Data Source \\
\hline pcimports & Logarithm of P\&C Imports in the WBC & UN Comtrade database \\
\hline pcexports & Logarithm of P\&C Exports from the WBC & UN Comtrade database \\
\hline pctotal & Logarithm of $\mathrm{P} \& \mathrm{C}$ total trade in the WBC & UN Comtrade database \\
\hline size & $\begin{array}{l}\text { Logarithm of the GDP of the home country multiplied by the } \\
\text { GDP of the foreign country }\end{array}$ & $\begin{array}{l}\text { World Development } \\
\text { Indicators - World Bank }\end{array}$ \\
\hline dist & Weighted geographical distance between countries & $\begin{array}{l}\text { Institute for Research on the } \\
\text { International Economy- } \\
\text { CEPII distance database }\end{array}$ \\
\hline border & $\begin{array}{l}\text { Dummy variable ( } 1 \text { if the partner countries shares a border } \\
\text { and } 0 \text { if not) }\end{array}$ & \\
\hline endow & $\begin{array}{l}\text { An index of per capita GDP of } i \text { relative to that of } j \text {, adjusted } \\
\text { by the bilateral exchange rate }\end{array}$ & $\begin{array}{l}\text { World Development } \\
\text { Indicators - World Bank }\end{array}$ \\
\hline ssize & Logarithm of similarity index by Helpman 1987 & $\begin{array}{l}\text { World Development } \\
\text { Indicators - World Bank }\end{array}$ \\
\hline infra & $\begin{array}{l}\text { Logarithm of the minimum value of the number of telephone } \\
\text { lines in both countries }\end{array}$ & $\begin{array}{l}\text { World Development } \\
\text { Indicators - World Bank }\end{array}$ \\
\hline instit & $\begin{array}{l}\text { Absolute difference in the Freedom House index between } \\
\text { partner countries }\end{array}$ & $\begin{array}{l}\text { Freedom House - Freedom } \\
\text { in the World Index }\end{array}$ \\
\hline yugo & $\begin{array}{l}\text { Dummy variable ( } 1 \text { if a WB country was part of the former } \\
\text { Yugoslavia and } 0 \text { if not) }\end{array}$ & \\
\hline saa & $\begin{array}{l}\text { Dummy variable ( } 1 \text { if a WB country has an SAA with the EU } \\
\text { and } 0 \text { if not) }\end{array}$ & \\
\hline fdi & $\begin{array}{l}\text { Logarithm of the stock of foreign direct investment in the } \\
\text { WB country }\end{array}$ & $\begin{array}{l}\text { World Development } \\
\text { Indicators - World Bank }\end{array}$ \\
\hline exch & Real effective exchange rate between countries & UNCTAD database \\
\hline
\end{tabular}


Table A3. Estimation results for parts and components trade. Country-pair fixed effects

\begin{tabular}{|c|c|c|c|c|c|c|}
\hline \multirow{4}{*}{$\begin{array}{l}\text { Dependent } \\
\text { variable }\end{array}$} & \multicolumn{6}{|c|}{ Parts and components } \\
\hline & \multicolumn{2}{|c|}{ Imports } & \multicolumn{2}{|c|}{ Exports } & \multicolumn{2}{|c|}{ Imports+Exports } \\
\hline & Model 1 & Model 2 & Model 1 & Model 2 & Model 1 & Model 2 \\
\hline & $\begin{array}{c}\text { Random } \\
\text { Effects }\end{array}$ & $\begin{array}{c}\text { Fixed } \\
\text { Effects. }\end{array}$ & $\begin{array}{l}\text { Fixed } \\
\text { Effects }\end{array}$ & $\begin{array}{c}\text { Random } \\
\text { Effects }\end{array}$ & $\begin{array}{l}\text { Fixed } \\
\text { Effects }\end{array}$ & $\begin{array}{c}\text { Random } \\
\text { Effects }\end{array}$ \\
\hline size & $\begin{array}{c}0.720 \text { *** } \\
(0.056)\end{array}$ & $\begin{array}{c}0.887^{* * \star} \\
(0.135)\end{array}$ & $\begin{array}{c}0.752 \text { *** } \\
(0.105)\end{array}$ & $\begin{array}{c}0.921 \text { *** } \\
(0.105)\end{array}$ & $\begin{array}{c}0.678 \text { *** } \\
(0.057)\end{array}$ & $\begin{array}{c}0.896 \text { *** } \\
(0.061)\end{array}$ \\
\hline dist & $\begin{array}{l}-0.341 \\
(0.241)\end{array}$ & & & $\begin{array}{c}-3.072 \text { *** } \\
(0.356)\end{array}$ & & $\begin{array}{c}-0.836 \text { *** } \\
(0.177)\end{array}$ \\
\hline border & $\begin{array}{l}1.231 \text { ** } \\
(0.542)\end{array}$ & & & $\begin{array}{c}0.002 \\
(0.435)\end{array}$ & & $\begin{array}{c}0.811 \text { *** } \\
(0.299)\end{array}$ \\
\hline endow & $\begin{array}{l}-0.238 \\
(0.184)\end{array}$ & $\begin{array}{l}-0.061 \\
(0.302)\end{array}$ & $\begin{array}{l}-0.452 \\
(0.358)\end{array}$ & $\begin{array}{c}0.633 * * * \\
(0.204)\end{array}$ & $\begin{array}{l}-0.087 \\
(0.200)\end{array}$ & $\begin{array}{c}0.072 \\
(0.078)\end{array}$ \\
\hline ssize & $\begin{array}{c}0.101 \\
(0.127)\end{array}$ & $\begin{array}{c}0.319 \\
(0.348)\end{array}$ & $\begin{array}{c}0.482 \\
(0.320)\end{array}$ & $\begin{array}{l}-0.284 \text { * } \\
(0.164)\end{array}$ & $\begin{array}{c}0.307 \\
(0.206)\end{array}$ & $\begin{array}{c}0.106 \\
(0.103)\end{array}$ \\
\hline infra & & $\begin{array}{l}0.635^{*} \\
(0.388)\end{array}$ & & $\begin{array}{c}1.827 * * \star \\
(0.331)\end{array}$ & & $\begin{array}{c}0.601 * * * \\
(0.187)\end{array}$ \\
\hline instit & & $\begin{array}{c}0.088 \\
(0.101)\end{array}$ & & $\begin{array}{c}0.359 * * * \\
(0.119)\end{array}$ & & $\begin{array}{c}0.252 * * * \\
(0.083)\end{array}$ \\
\hline yugo & & Omitted & & $\begin{array}{c}1.639 * * * \\
(0.409)\end{array}$ & & $\begin{array}{c}1.908 * * * \\
(0.317)\end{array}$ \\
\hline saa & & $\begin{array}{l}-0.067 \\
(0.119)\end{array}$ & & $\begin{array}{c}0.064 \\
(0.198)\end{array}$ & & $\begin{array}{l}-0.008 \\
(0.103)\end{array}$ \\
\hline fdi & & $\begin{array}{l}-0.240 * \\
(0.143)\end{array}$ & & $\begin{array}{l}-0.013 \\
(0.149)\end{array}$ & & $\begin{array}{c}-0.172 * * \\
(0.082)\end{array}$ \\
\hline exch & & $\begin{array}{c}-0.662 \text { ** } \\
(0.307)\end{array}$ & & $\begin{array}{c}0.076 \\
(0.067)\end{array}$ & & $\begin{array}{c}0.006 \\
(0.048)\end{array}$ \\
\hline const & $\begin{array}{c}-17.96 \text { *** } \\
(2.832)\end{array}$ & $\begin{array}{c}-27.93 \text { *** } \\
(7.339)\end{array}$ & $\begin{array}{c}-21.78 \text { *** } \\
(5.760)\end{array}$ & $\begin{array}{c}-18.83 \text { *** } \\
(3.581)\end{array}$ & $\begin{array}{c}-16.92 \text { *** } \\
(3.249)\end{array}$ & $\begin{array}{c}-24.85 * * * \\
(2.673)\end{array}$ \\
\hline $\begin{array}{l}\text { Num. of } \\
\text { observations }\end{array}$ & 374 & 352 & 351 & 329 & 378 & 355 \\
\hline $\begin{array}{l}\text { Adjusted } \mathrm{R}^{2} \\
\text { Hausmann }\end{array}$ & 0.5022 & 0.5008 & 0.3629 & 0.7195 & 0.5391 & 0.7395 \\
\hline Test & $\begin{array}{c}4.72 \\
0.1936 \\
\end{array}$ & $\begin{array}{c}16.23 \\
0.0392 \\
\end{array}$ & $\begin{array}{c}20.10 \\
0.0002 \\
\end{array}$ & $\begin{array}{c}11.70 \\
0.1653 \\
\end{array}$ & $\begin{array}{c}8.57 \\
0.0357\end{array}$ & $\begin{array}{c}13.38 \\
0.0995\end{array}$ \\
\hline
\end{tabular}


Table A4. Estimation results for final goods trade. Country-pair fixed effects

\begin{tabular}{|c|c|c|c|c|c|c|}
\hline \multirow{4}{*}{$\begin{array}{l}\text { Dependent } \\
\text { variable }\end{array}$} & \multicolumn{6}{|c|}{ Final goods } \\
\hline & \multicolumn{2}{|c|}{ Imports } & \multicolumn{2}{|c|}{ Exports } & \multicolumn{2}{|c|}{ Imports+Exports } \\
\hline & Model 1 & Model 2 & Model 1 & Model 2 & Model 1 & Model 2 \\
\hline & $\begin{array}{c}\text { Random } \\
\text { Effects }\end{array}$ & $\begin{array}{l}\text { Fixed } \\
\text { Effects }\end{array}$ & $\begin{array}{l}\text { Fixed } \\
\text { Effects }\end{array}$ & $\begin{array}{l}\text { Fixed } \\
\text { Effects }\end{array}$ & $\begin{array}{l}\text { Random } \\
\text { Effects }\end{array}$ & $\begin{array}{l}\text { Fixed } \\
\text { Effects }\end{array}$ \\
\hline size & $\begin{array}{c}0.801 \text { *** } \\
(0.064)\end{array}$ & $\begin{array}{c}0.875 * * * \\
(0.130)\end{array}$ & $\begin{array}{c}0.823 * * * \\
(0.117)\end{array}$ & $\begin{array}{c}1.027 * \star \star \\
(0.227)\end{array}$ & $\begin{array}{c}0.767 * \star * \\
(0.060)\end{array}$ & $\begin{array}{c}0.803 * * * \\
(0.107)\end{array}$ \\
\hline dist & $\begin{array}{c}-0.703 * * * \\
(0.236)\end{array}$ & & & & $\begin{array}{c}-0.885 * * * \\
(0.231)\end{array}$ & \\
\hline border & $\begin{array}{c}0.877^{* *} \\
(0.424)\end{array}$ & & & & $\begin{array}{c}1.012 \text { *** } \\
(0.375)\end{array}$ & \\
\hline endow & $\begin{array}{c}0.048 \\
(0.184)\end{array}$ & $\begin{array}{l}-0.338 \\
(0.336)\end{array}$ & $\begin{array}{l}-0.442 \\
(0.363)\end{array}$ & $\begin{array}{c}-0.654 \text { ** } \\
(0.278)\end{array}$ & $\begin{array}{c}0.194 \\
(0.146)\end{array}$ & $\begin{array}{l}-0.361 \\
(0.340)\end{array}$ \\
\hline ssize & $\begin{array}{l}-0.072 \\
(0.122)\end{array}$ & $\begin{array}{c}0.001 \\
(0.230)\end{array}$ & $\begin{array}{c}0.135 \\
(0.462)\end{array}$ & $\begin{array}{c}1.028 \\
(0.677)\end{array}$ & $\begin{array}{l}-0.121 \\
(0.123)\end{array}$ & $\begin{array}{c}0.020 \\
(0.214)\end{array}$ \\
\hline infra & & $\begin{array}{c}0.897 * * * \\
(0.270)\end{array}$ & & $\begin{array}{c}1.307 * \star \star \\
(0.426)\end{array}$ & & $\begin{array}{c}0.728 * \star \star \\
(0.202)\end{array}$ \\
\hline instit & & $\begin{array}{c}0.119 \\
(0.088)\end{array}$ & & $\begin{array}{c}0.284 \text { ** } \\
(0.122)\end{array}$ & & $\begin{array}{l}0.135 \text { ** } \\
(0.061)\end{array}$ \\
\hline yugo & & Omitted & & Omitted & & Omitted \\
\hline saa & & $\begin{array}{l}-0.110 \\
(0.113)\end{array}$ & & $\begin{array}{c}0.121 \\
(0.198)\end{array}$ & & $\begin{array}{c}-0.082 \\
(0.091)\end{array}$ \\
\hline fdi & & $\begin{array}{l}-0.213 \text { * } \\
(0.124)\end{array}$ & & $\begin{array}{c}-0.292 \\
(0.234)\end{array}$ & & $\begin{array}{c}-0.129 \\
(0.107)\end{array}$ \\
\hline exch & & $\begin{array}{l}-0.392 \\
(0.368)\end{array}$ & & $\begin{array}{l}0.802 \text { * } \\
(0.429)\end{array}$ & & $\begin{array}{c}-0.483 \text { ** } \\
(0.246)\end{array}$ \\
\hline const & $\begin{array}{c}-18.18 \text { *** } \\
(2.783)\end{array}$ & $\begin{array}{c}-27.55 * * * \\
(6.669)\end{array}$ & $\begin{array}{c}-24.72 \text { *** } \\
(6.889)\end{array}$ & $\begin{array}{c}-37.37 \\
(11.130)\end{array}$ & $\begin{array}{c}-15.07 \text { *** } \\
(2.438)\end{array}$ & $\begin{array}{c}-23.16 \text { *** } \\
(5.464)\end{array}$ \\
\hline $\begin{array}{l}\text { Num. of } \\
\text { observations }\end{array}$ & 379 & 356 & 366 & 343 & 379 & 356 \\
\hline $\begin{array}{l}\text { Adjusted } \mathrm{R}^{2} \\
\text { Hausman }\end{array}$ & 0.5952 & 0.5796 & 0.4045 & 0.4576 & 0.5928 & 0.6382 \\
\hline Test & $\begin{array}{c}6.19 \\
0.1026 \\
\end{array}$ & $\begin{array}{c}18.95 \\
0.0151 \\
\end{array}$ & $\begin{array}{c}10.71 \\
0.0134 \\
\end{array}$ & $\begin{array}{c}18.47 \\
0.0180 \\
\end{array}$ & $\begin{array}{c}4.37 \\
0.2243 \\
\end{array}$ & $\begin{array}{r}21.50 \\
0.0059 \\
\end{array}$ \\
\hline
\end{tabular}




\section{FIGURES}

Figure 1. Annual growth in parts and components trade. Period 2000-2010

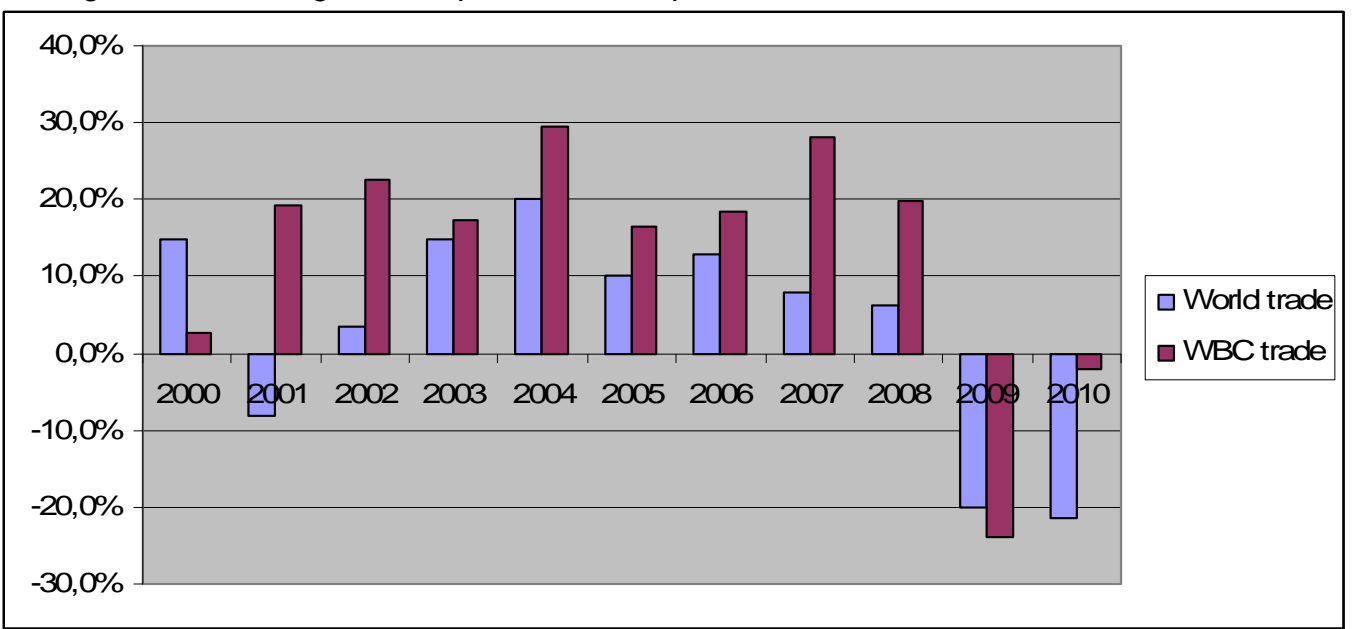

Source: UN Comtrade and author's own calculation. 


\section{TABLES}

Table 1. Foreign direct investment as \% of GDP

\begin{tabular}{|c|c|c|c|c|c|c|c|c|c|c|c|}
\hline & 2000 & 2001 & 2002 & 2003 & 2004 & 2005 & 2006 & 2007 & 2008 & 2009 & 2010 \\
\hline Albania & 3.9 & 5.1 & 3.0 & 3.1 & 4.6 & 3.1 & 3.6 & 6.2 & 7.4 & 8.0 & 9.4 \\
\hline $\begin{array}{l}\text { Bosnia and } \\
\text { Herzegovina }\end{array}$ & 2.7 & 2.1 & 4.0 & 4.6 & 7.1 & 5.6 & 6.3 & 13.6 & 5.3 & 1.4 & 1.4 \\
\hline Croatia & 5.2 & 6.9 & 4.1 & 6.0 & 2.6 & 4.0 & 6.9 & 8.4 & 8.6 & 4.5 & 0.5 \\
\hline Macedonia & 6.0 & 13.0 & 2.8 & 2.5 & 5.9 & 1.6 & 6.5 & 8.6 & 6.0 & 2.1 & 3.2 \\
\hline $\begin{array}{l}\text { Serbia and } \\
\text { Montenegro }\end{array}$ & 0.9 & 1.6 & 3.8 & 7.2 & 4.3 & 8.1 & 17.0 & 17.1 & 13.8 & 20.8 & 11.0 \\
\hline
\end{tabular}

Table 2: Trade in (total) machinery and transport equipment and parts and components of the same groups: 2000-2009 (mil. US\$)

\begin{tabular}{|c|c|c|c|c|c|c|}
\hline & \multicolumn{2}{|c|}{$\begin{array}{c}\text { Machinery final goods } \\
\text { trade }\end{array}$} & \multicolumn{2}{|c|}{$\begin{array}{l}\mathrm{P} \& \mathrm{C} \\
\text { trade }\end{array}$} & \multicolumn{2}{|c|}{$\begin{array}{l}\text { P\&C/Machinery final } \\
\text { goods }\end{array}$} \\
\hline & Imports & Exports & Imports & Exports & Imports & Exports \\
\hline \multicolumn{7}{|l|}{ World } \\
\hline 2000 & $2,203,795$ & $2,162,897$ & $1,117,222$ & $1,117,097$ & $51 \%$ & $52 \%$ \\
\hline 2004 & $3,075,915$ & $3,031,530$ & $1,474,657$ & $1,456,353$ & $48 \%$ & $48 \%$ \\
\hline 2009 & $3,793,472$ & $3,848,402$ & $1,706,771$ & $1,634,764$ & $45 \%$ & $42 \%$ \\
\hline \multicolumn{7}{|l|}{$\begin{array}{l}\text { Western } \\
\text { Balkans }\end{array}$} \\
\hline 2000 & 4,823 & 2,291 & 678 & 437 & $14 \%$ & $19 \%$ \\
\hline 2004 & 13,614 & 5,455 & 2,171 & 1,119 & $16 \%$ & $21 \%$ \\
\hline 2009 * & 16,721 & 7,925 & 2,847 & 2,449 & $17 \%$ & $31 \%$ \\
\hline \multirow[t]{2}{*}{2009 ** } & 14,104 & 6,487 & 2,425 & 1,940 & $17 \%$ & $30 \%$ \\
\hline & $192 \%$ & $183 \%$ & $257 \%$ & $343 \%$ & & \\
\hline \multicolumn{7}{|l|}{ EU-10 } \\
\hline 2000 & 52,382 & 52,046 & 28,451 & 22,907 & $54 \%$ & $44 \%$ \\
\hline 2004 & 109,529 & 115,869 & 57,974 & 54,895 & $53 \%$ & $47 \%$ \\
\hline \multirow[t]{2}{*}{2009} & 152,759 & 211,585 & 91,989 & 80,651 & $60 \%$ & $38 \%$ \\
\hline & $191 \%$ & $306 \%$ & $223 \%$ & $252 \%$ & & \\
\hline \multicolumn{7}{|l|}{ EU-15 } \\
\hline 2000 & 780,221 & 835,583 & 346,150 & 346.907 & $44 \%$ & $42 \%$ \\
\hline 2004 & $1,140,510$ & $1,220,609$ & 454,234 & 487.889 & $40 \%$ & $40 \%$ \\
\hline \multirow[t]{2}{*}{2009} & $1,289,273$ & $1,335,803$ & 456,219 & 507.219 & $35 \%$ & $38 \%$ \\
\hline & $65 \%$ & $59 \%$ & $31 \%$ & $46 \%$ & & \\
\hline
\end{tabular}

* Data for the WBC with Bosnia and Herzegovina. The comparison is with 2004.

** Data for the WBC without Bosnia and Herzegovina. The comparison is with 2000.

Source: UN Comtrade database and own calculations. 
Table 3. Estimation results for parts and components trade. Home-country fixed effects

\begin{tabular}{|c|c|c|c|c|c|c|}
\hline \multirow{4}{*}{$\begin{array}{l}\text { Dependent } \\
\text { variable }\end{array}$} & \multicolumn{6}{|c|}{ Parts and components } \\
\hline & \multicolumn{2}{|c|}{ Imports } & \multicolumn{2}{|c|}{ Exports } & \multicolumn{2}{|c|}{ Imports+Exports } \\
\hline & Model 1 & Model 2 & Model 1 & Model 2 & Model 1 & Model 2 \\
\hline & $\begin{array}{c}\text { Random } \\
\text { Effects }\end{array}$ & $\begin{array}{l}\text { Fixed } \\
\text { Effects }\end{array}$ & $\begin{array}{c}\text { Fixed } \\
\text { Effects }\end{array}$ & $\begin{array}{l}\text { Random } \\
\text { Effects }\end{array}$ & $\begin{array}{l}\text { Fixed } \\
\text { Effects }\end{array}$ & $\begin{array}{c}\text { Random } \\
\text { Effects }\end{array}$ \\
\hline \multirow[t]{2}{*}{ size } & $0.743 * \star \star$ & $1.158 * \star \star$ & $0.872 * \star \star$ & $0.868 * * \star$ & $0.881 * * \star$ & $0.855 * \star \star$ \\
\hline & $(0.102)$ & $(0.051)$ & $(0.115)$ & $(0.090)$ & $(0.106)$ & $(0.064)$ \\
\hline \multirow[t]{2}{*}{ dist } & $-0.488 * *$ & $-0.689 * *$ & $-2.921 * * *$ & $-3.067 * * \star$ & $-0.914 * * \star$ & $-0.916 * * *$ \\
\hline & $(0.181)$ & $(0.231)$ & $(0.481)$ & $(0.383)$ & $(0.228)$ & $(0.178)$ \\
\hline \multirow[t]{2}{*}{ border } & $1.148 * \star \star$ & 0.950 & 0.182 & 0.008 & $1.024 * \star \star$ & $0.872 *$ \\
\hline & $(0.267)$ & $(0.522)$ & $(0.794)$ & $(0.983)$ & $(0.220)$ & $(0.481)$ \\
\hline \multirow{2}{*}{ endow } & -0.225 * & 0.176 & $0.349 * *$ & $0.681 * * *$ & 0.131 & 0.077 * \\
\hline & $(0.100)$ & $(0.110)$ & $(0.091)$ & $(0.070)$ & $(0.089)$ & $(0.043)$ \\
\hline \multirow[t]{2}{*}{ ssize } & 0.051 & 0.382 ** & $-0.313 * *$ & $-0.354 * * *$ & 0.152 & 0.043 \\
\hline & $(0.152)$ & $(0.116)$ & $(0.126)$ & $(0.102)$ & (0.111) & $(0.057)$ \\
\hline \multirow[t]{2}{*}{ infra } & & 1.674 ** & & 1.938 *** & & 0.664 *** \\
\hline & & $(0.611)$ & & $(0.308)$ & & $(0.141)$ \\
\hline \multirow[t]{2}{*}{ instit } & & $0.430 * \star \star$ & & $0.450 * * *$ & & $0.386 * \star \star$ \\
\hline & & (0.069) & & $(0.155)$ & & $(0.083)$ \\
\hline \multirow[t]{2}{*}{ yugo } & & $2.073 * \star \star$ & & $1.452 * \star \star$ & & 1.851 *** \\
\hline & & $(0.259)$ & & $(0.275)$ & & $(0.199)$ \\
\hline \multirow[t]{2}{*}{ saa } & & 0.132 & & -0.134 & & -0.010 \\
\hline & & $(0.067)$ & & $(0.175)$ & & $(0.075)$ \\
\hline \multirow[t]{2}{*}{ fdi } & & $-0.706 * \star \star$ & & $0.224 * * \star$ & & -0.106 \\
\hline & & (0.169) & & $(0.081)$ & & $(0.092)$ \\
\hline \multirow[t]{2}{*}{ exch } & & 0.003 & & 0.082 * & & 0.013 \\
\hline & & $(0.080)$ & & $(0.046)$ & & (0.029) \\
\hline \multirow[t]{2}{*}{ const } & -18.17 ** & 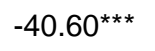 & -10.62 ** & $-17.58 * * *$ & $-21.53 * \star *$ & $-23.10 * * *$ \\
\hline & $(4.577)$ & (3.118) & (3.954) & $(1.451)$ & $(4.835)$ & $(2.041)$ \\
\hline Num. of & & & & & 378 & 355 \\
\hline $\begin{array}{l}\text { observations } \\
\text { Adjusted } \mathrm{R}^{2}\end{array}$ & $\begin{array}{c}374 \\
0.4308\end{array}$ & $\begin{array}{c}352 \\
0.6543\end{array}$ & $\begin{array}{c}351 \\
0.4935\end{array}$ & $\begin{array}{c}329 \\
0.7230\end{array}$ & $\begin{array}{c}3 / 8 \\
0.5628\end{array}$ & $\begin{array}{c}355 \\
0.7438\end{array}$ \\
\hline
\end{tabular}

Data source: Authors' own calculation based on UN Comtrade database.

Notes: figures in parenthesis are the standard errors. ${ }^{* \star *} ;{ }^{* \star}$ and * indicate that the results are statistically significant at the $1 ; 5$ and 10 percent levels, respectively 
Table 4. Estimation results for final goods trade. Home-country fixed effects

\begin{tabular}{|c|c|c|c|c|c|c|}
\hline \multirow{4}{*}{$\begin{array}{l}\text { Dependent } \\
\text { variable }\end{array}$} & \multicolumn{6}{|c|}{ Final goods } \\
\hline & \multicolumn{2}{|c|}{ Imports } & \multicolumn{2}{|c|}{ Exports } & \multicolumn{2}{|c|}{ Imports+Exports } \\
\hline & Model 1 & Model 2 & Model 1 & Model 2 & Model 1 & Model 2 \\
\hline & $\begin{array}{l}\text { Random } \\
\text { Effects }\end{array}$ & $\begin{array}{l}\text { Fixed } \\
\text { Effects }\end{array}$ & $\begin{array}{l}\text { Fixed } \\
\text { Effects }\end{array}$ & $\begin{array}{l}\text { Fixed } \\
\text { Effects }\end{array}$ & $\begin{array}{l}\text { Random } \\
\text { Effects }\end{array}$ & $\begin{array}{l}\text { Fixed } \\
\text { Effects }\end{array}$ \\
\hline \multirow[t]{2}{*}{ size } & $0.879 * * \star$ & $1.200 * * \star$ & $0.880 * * \star$ & $0.777 * \star$ & $0.794 * * *$ & $0.744 * * \star$ \\
\hline & $(0.085)$ & $(0.125)$ & $(0.136)$ & $(0.202)$ & $(0.057)$ & $(0.069)$ \\
\hline \multirow[t]{2}{*}{ dist } & -0.596 *** & $-0.731 * * *$ & $-3.063 * \star *$ & -2.643 *** & $-0.845 * * *$ & 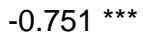 \\
\hline & $(0.136)$ & $(0.134)$ & $(0.201)$ & $(0.307)$ & $(0.080)$ & $(0.057)$ \\
\hline \multirow[t]{2}{*}{ border } & $0.890 * * \star$ & 0.784 * & 0.454 & 0.700 & 0.982 ** & $0.978 * \star *$ \\
\hline & $(0.352)$ & $(0.339)$ & $(0.581)$ & $(0.625)$ & $(0.304)$ & $(0.294)$ \\
\hline \multirow[t]{2}{*}{ endow } & 0.020 & 0.332 ** & 0.204 ** & 0.203 & 0.154 * & $0.240 * \star \star$ \\
\hline & $(0.082)$ & $(0.106)$ & $(0.058)$ & $(0.176)$ & $(0.060)$ & $(0.059)$ \\
\hline \multirow[t]{2}{*}{ ssize } & 0.103 ** & 0.376 ** & $0.489 * * \star$ & $-0.483 * *$ & -0.061 & $-0.140 * * *$ \\
\hline & $(0.043)$ & $(0.106)$ & $(0.046)$ & $(0.140)$ & $(0.088)$ & $(0.042)$ \\
\hline \multirow[t]{2}{*}{ infra } & & $1.193 * \star$ & & 0.356 & & $0.746 * * *$ \\
\hline & & $(0.384)$ & & $(0.631)$ & & $(0.115)$ \\
\hline \multirow{2}{*}{ instit } & & $0.281 * * \star$ & & 0.182 & & $0.205 * * *$ \\
\hline & & $(0.061)$ & & $(0.115)$ & & $(0.048)$ \\
\hline \multirow[t]{2}{*}{ yugo } & & 1.714 *** & & 1.558 * & & $1.449 * \star \star$ \\
\hline & & $(0.299)$ & & $(0.644)$ & & $(0.301)$ \\
\hline \multirow[t]{2}{*}{ saa } & & 0.080 & & 0.291 *** & & 0.187 *** \\
\hline & & (0.148) & & $(0.036)$ & & $(0.060)$ \\
\hline \multirow[t]{2}{*}{$f d i$} & & $-0.710 * * \star$ & & 0.179 * & & -0.143 ** \\
\hline & & $(0.116)$ & & $(0.071)$ & & $(0.073)$ \\
\hline \multirow[t]{2}{*}{ exch } & & -0.021 & & 0.206 * & & 0.047 * \\
\hline & & $(0.062)$ & & (0.092) & & $(0.027)$ \\
\hline \multirow[t]{2}{*}{ const } & 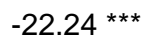 & $-38.71 * * \star$ & -8.86 & -9.35 & $-16.51 * * \star$ & $-17.45 * \star \star$ \\
\hline & (3.545) & $(4.758)$ & (5.548) & (8.379) & $(2.730)$ & $(2.263)$ \\
\hline $\begin{array}{l}\text { Num. of } \\
\text { observations }\end{array}$ & 379 & 356 & 366 & 343 & 379 & 356 \\
\hline Adjusted $\mathrm{R}^{2}$ & 0.6024 & 0.7210 & 0.5979 & 0.6856 & 0.5626 & 0.7777 \\
\hline
\end{tabular}

Data source: Authors' own calculation based on UN Comtrade database.

Notes: figures in parenthesis are the standard errors. ${ }^{\star \star *} ;{ }^{* \star}$ and * indicate that the results are statistically significant at the $1 ; 5$ and 10 percent levels, respectively 